\title{
Article \\ Titanium Dioxide Induces Apoptosis under UVA Irradiation via the Generation of Lysosomal Membrane Permeabilization-Dependent Reactive Oxygen Species in HaCat Cells
}

\author{
In Young Kim ${ }^{1}$, Tae Geol Lee ${ }^{1}$, Vytas Reipa ${ }^{2, *}$ and Min Beom Heo ${ }^{1, *}$ \\ 1 Nano-Safety Team, Safety Measurement Institute, Korea Research Institute of Standards and Science (KRISS), \\ Daejeon 34113, Korea; inyoungkim@kriss.re.kr (I.Y.K.); tglee@kriss.re.kr (T.G.L.) \\ 2 Materials Measurement Laboratory, Biosystems and Biomaterials Division, National Institute of Standards \\ and Technology, Gaithersburg, MD 20899, USA \\ * Correspondence: vytas@nist.gov (V.R.); mbheo@kriss.re.kr (M.B.H.); \\ Tel.: +1-(301)-975-5056 (V.R.); +82-(042)-604-1052 (M.B.H.)
}

check for updates

Citation: Kim, I.Y.; Lee, T.G.; Reipa,

V.; Heo, M.B. Titanium Dioxide

Induces Apoptosis under UVA

Irradiation via the Generation of

Lysosomal Membrane

Permeabilization-Dependent Reactive Oxygen Species in HaCat Cells.

Nanomaterials 2021, 11, 1943. https:// doi.org/10.3390/nano11081943

Academic Editor: Olivier Joubert

Received: 29 June 2021

Accepted: 23 July 2021

Published: 28 July 2021

Publisher's Note: MDPI stays neutral with regard to jurisdictional claims in published maps and institutional affiliations.

Copyright: (c) 2021 by the authors. Licensee MDPI, Basel, Switzerland. This article is an open access article distributed under the terms and conditions of the Creative Commons Attribution (CC BY) license (https:/ / creativecommons.org/licenses/by/ $4.0 /)$.

\begin{abstract}
Titanium dioxide nanoparticles $\left(\mathrm{TiO}_{2} \mathrm{NPs}\right.$ ) have wide commercial applications, owing to their small size; however, the biosafety of $\mathrm{TiO}_{2} \mathrm{NPs}$ should be evaluated further. In this study, we aimed to investigate the cytotoxicity of $\mathrm{TiO}_{2} \mathrm{NPs}$ in the presence and absence of ultraviolet $\mathrm{A}$ (UVA) irradiation in human keratinocyte $\mathrm{HaCaT}$ cells. $\mathrm{TiO}_{2} \mathrm{NPs}$ did not significantly affect cell viability in the absence of UVA irradiation. Nonetheless, UVA-irradiated $\mathrm{TiO}_{2} \mathrm{NPs}_{\text {induced caspase-dependent }}$ apoptosis of HaCaT cells. Exposure of HaCaT cells to $\mathrm{TiO}_{2} \mathrm{NPs}_{\text {and }} \mathrm{UVA}$ resulted in reactive oxygen species (ROS) generation and lysosomal membrane permeabilization (LMP); both effects were not observed in the absence of UVA irradiation. An analysis of the relationship between LMP and ROS, using CA-074 as a cathepsin inhibitor or NAC as an antioxidant, showed that LMP stimulates ROS generation under these conditions. These results imply that LMP-dependent oxidative stress plays a critical role in the UVA phototoxicity of $\mathrm{TiO}_{2} \mathrm{NPs}$ in $\mathrm{HaCaT}$ cells.
\end{abstract}

Keywords: titanium dioxide nanoparticles $\left(\mathrm{TiO}_{2} \mathrm{NPs}\right)$; ultraviolet A (UVA); phototoxicity; lysosomal membrane permeabilization (LMP); reactive oxygen species (ROS)

\section{Introduction}

The potential toxicity of nanomaterials (NMs) to humans and the environment has been recognized since the dawn of nanotechnology [1]. This is because their physicochemical properties are highly dependent on small particle size, resulting in a high surface-tovolume ratio and enhanced transport across biological barriers [2]. Consequently, some materials, while benign in bulk form, become toxic when prepared in nano sizes [3].

Titanium dioxide nanoparticles $\left(\mathrm{TiO}_{2} \mathrm{NPs}\right)$ are the highest volume-NM employed in water purification, paint, food additives, and personal care products, including sunscreens. There is a high probability that these nanoparticles (NPs) will come in contact with human skin and mucous membranes, subsequently entering the body [4]. Numerous studies have confirmed that the overall cytotoxicity of $\mathrm{TiO}_{2} \mathrm{NPs}$ is rather low, compared with that of several widely produced NMs [5-7], and they are "generally regarded as safe (GRAS)" by regulatory agencies [8]. However, some countries lately have removed $\mathrm{TiO}_{2}$ from the GRAS designation owing to in vivo evidence of its potential toxicity [9]. In addition, in vitro studies with mammalian cells have shown that $\mathrm{TiO}_{2} \mathrm{NPs}$ induce oxidative stress and apoptosis [10-13], suggesting that the safety profile of $\mathrm{TiO}_{2} \mathrm{NPs}$ is still unclear.

A key determinant of NP toxicity is their ability to penetrate cellular membranes and their subcellular localization. NPs often accumulate in the lysosomes [14] via processes such as autophagy and endocytosis. Autophagy, a main catabolic pathway in mammalian 
cells, is involved in the elimination of foreign substances and cell degradation products by encapsulating them with a double membrane, thus forming the autophagosomes and subsequently fusing with lysosomes. Following their fusion, substances in autophagosomes are digested by lysosomal hydrolytic enzymes. Impairment of this process can lead to a variety of human diseases, and at the molecular level, it is linked to the damage of specific autophagy system components such as lysosomes. The uptake and accumulation of positively charged polystyrene nanoparticles have been reported to cause progressive lysosomal alterations, from early mild lysosomal membrane permeabilization (LMP), followed by lysosomal expansion and extensive LMP [13] after prolonged exposures. Substantial lysosomal damage leads to cathepsin release, thereby inducing cell apoptosis and necrosis [14-16]. Exposure to $\mathrm{TiO}_{2} \mathrm{NPs}$ of various sizes for $24 \mathrm{~h}$ has been found to upregulate autophagic flux, lysosomal dysfunction, and membrane permeabilization, whereas a $72 \mathrm{~h}$ exposure abrogates autophagic flux $[17,18]$.

Interest in $\mathrm{TiO}_{2} \mathrm{NPs}$ is mostly owing to their photocatalytic activity, which is a major contributor to the toxicological effects of $\mathrm{TiO}_{2} \mathrm{NPs}$ when they interact with biomolecules $[19,20]$. Phototoxicity is triggered by adverse chemical reactions supported by photocatalytically active materials under illumination. The principal cause of cell death mediated by photoactivated $\mathrm{TiO}_{2} \mathrm{NPs}$ is the oxidative damage of proteins, nucleic acids, and lipids caused by excessive reactive oxygen species (ROS) generation when $\mathrm{TiO}_{2} \mathrm{NP}$ absorb UV light and the excited charge carriers react with oxygen and/or water [21]. Therefore, the safety of $\mathrm{TiO}_{2}$ NPs is highly dependent on lighting conditions during their human and environmental exposure [22].

Due to the lack of clarity regarding the effects of the photocatalytic activity of $\mathrm{TiO}_{2}$ NPs on the human body, some regulators have restricted their use in cosmetic applications, including sunscreen [23]. Photocatalytic activity is a well-established physicochemical property of $\mathrm{TiO}_{2} \mathrm{NPs}$ and is directly related to cellular toxicity under ultraviolet (UV) irradiation $[24,25]$. These properties also serve as a basis for the development of photodynamic therapies, as $\mathrm{TiO}_{2} \mathrm{NPs}$ under UVA irradiation $(310 \mathrm{~nm}<\lambda<390 \mathrm{~nm}$ ) induce cell death in colon carcinoma, melanoma, cervix adenocarcinoma, fibroblasts, and keratinocytes [26-31].

Considering the increasing interest in the nanomedical application of photoexcited $\mathrm{TiO}_{2} \mathrm{NPs}$ and concerns about their safety in personal care products, the mechanistic aspects of cell impairment have lately become a focus of experimental studies [32,33]. Besides the production of ROS and ensuing oxidative stress as well-established underlying factors for the adverse biological reactions, other attributes such as NP subcellular localization may alter the phototoxic effects of $\mathrm{TiO}_{2} \mathrm{NPs}$. Photo-induced damage to the endoplasmic reticulum often leads to cell death by autophagy [34]. A significant increase in the number of autophagic vesicles, along with the degradation of the endoplasmic reticulum, but no inflammation, in $\mathrm{TiO}_{2}$-exposed human bronchial epithelial cells, has been reported by $\mathrm{Yu}$ et al. [35]. Moreover, $\mathrm{TiO}_{2} \mathrm{NP}$-generated $\mathrm{ROS}$ can also promote the uncoupling of the mitochondrial respiratory chains, resulting in excess intracellular ROS production from the superoxide anion [36]. Other studies have shown that UV irradiation aggravates LMP, which leads to the intrinsic apoptosis of melanocytes [37,38] and cell necroptosis by hindering autophagosome-lysosome fusion [39]. These findings suggest that the role of photoexcitation in autophagy and lysosomal damage is not well established [40].

In this study, we comprehensively investigated the biological mechanism of phototoxicity by $\mathrm{TiO}_{2}$ in $\mathrm{HaCaT}$ cells and found evidence of the lysosomal membrane damage that facilitates intracellular ROS generation. We focused on the combined effects of $\mathrm{TiO}_{2}$ $\mathrm{NP}$ uptake and resulting UVA sensitization on lysosomal membrane integrity. We found evidence that major lysosomal destabilization occurs only when accumulated $\mathrm{TiO}_{2} \mathrm{NPs}$ are photoexcited by UVA. Consequently, the loss of lysosomal membrane integrity is essential for $\mathrm{TiO}_{2} \mathrm{NPs}$ and UVA-induced ROS surge. Moreover, our data strongly suggest that caspase-dependent apoptosis is a key mechanism of $\mathrm{HaCaT}$ cell death induced by their exposure to internalized and photoexcited $\mathrm{TiO}_{2} \mathrm{NPs}$. 


\section{Materials and Methods}

\subsection{Chemicals}

z-VAD-fmk was purchased from R\&D system (Minneapolis, MN, USA). 5-(and-6)chloromethyl-2' ${ }^{\prime} 7^{\prime}$-dichlorodihydrofluorescein diacetate, acetyl ester (CM-H ${ }_{2}$ DCF-DA) was purchased from Thermo Fisher Scientific (Waltham, MA, USA). Chlorpromazine hydrochloride, propidium iodide, acridine orange $(\mathrm{AO})$, hydrogen peroxide $\left(\mathrm{H}_{2} \mathrm{O}_{2}\right)$, Nacetyl-L-cysteine (NAC), and (L-3-trans-(propylcarbamyl)oxirane-2-carbonyl)-L-isoleucylL-proline (CA-074) were purchased from Sigma-Aldrich (St. Louis, MO, USA).

\subsection{Cell Culture}

Human keratinocyte HaCaT cells (Cell Line Services, Eppelheim, Germany) were maintained in Dulbecco's modified Eagle medium containing 10\% fetal bovine serum and $1 \%$ penicillin-streptomycin (all obtained from GIBCO-BRL, Grand Island, NY, USA). The cells were incubated under $5 \% \mathrm{CO}_{2}$ at $37^{\circ} \mathrm{C}$.

\subsection{Preparation and Characterization of $\mathrm{TiO}_{2} \mathrm{NP}$ Suspension}

$\mathrm{TiO}_{2}$ NPs (AEROXIDE ${ }^{\circledR} \mathrm{TiO}_{2}$ P25) were obtained from Evonik Industries AG (Essen, Germany). They were dispersed in a complete medium according to the National Institute of Standards and Technology (USA) special publication 1200-4 [41]. Particle size distribution of $\mathrm{TiO}_{2}$ NPs was determined by dynamic light scattering (DLS; ZEN5600, Malvern Panalytical, Worcestershire, England). Zeta potential was measured using the same equipment mentioned above.

\subsection{Treatment with $\mathrm{TiO}_{2} \mathrm{NPS}$ and $\mathrm{UVA}$}

A graphic summary of the experimental procedure is shown in Figure 1. HaCaT cells were plated in two 96-well plates and then incubated for $24 \mathrm{~h}$. On a subsequent day, the surface-adhered cells were exposed to $25-200 \mu \mathrm{g} / \mathrm{mL} \mathrm{TiO}_{2} \mathrm{NPs}_{\text {for }} 24 \mathrm{~h}$. The treated cells were washed twice with warm phosphate-buffered saline (PBS) (Sigma-Aldrich, St. Louis, $\mathrm{MO}, \mathrm{USA}$ ) to separate extracellular $\mathrm{TiO}_{2} \mathrm{NPs}$. While one plate was directly irradiated with UVA for $20 \mathrm{~min}$ (light dose $\mathrm{P}=5 \mathrm{~J} / \mathrm{cm}^{2}$, exposure group), the other plate was protected from UVA exposure by covering with foil (dark group). Following post-irradiation stabilization for $20 \mathrm{~min}$, HBSS was replaced with a complete medium, and the cells were incubated for $24 \mathrm{~h}$.

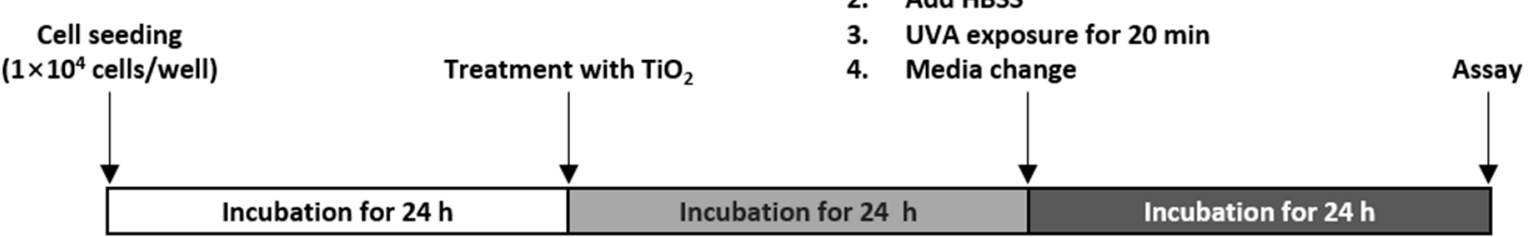

Figure 1. Outline of the experimental procedure.

\subsection{Cell Viability Assay}

The cells were seeded in 96-well plates and treated as described above. The CellTiterGlo Luminescent Cell Viability kit (Promega, Madison, WI, USA) was employed to assess cell viability, according to the manufacturer's instructions. The $\mathrm{IC}_{50}$, the concentration at which cell growth is inhibited by 50\%, compared with the untreated control, was estimated using GraphPad Prism software 7.0 (GraphPad Software Inc., San Diego, CA, USA). Since treatment with $200 \mu \mathrm{g} / \mathrm{mL} \mathrm{TiO}_{2}$ in the dark did not cause more than $50 \%$ viability decrease in $\mathrm{HaCaT}$ cells, the $\mathrm{IC}_{50}$ was estimated from the available viability data using GraphPad Prism software 7.0. 


\subsection{Measurement of Lactate Dehydrogenase Release}

A lactate dehydrogenase (LDH) detection kit (CytoTox $96^{\circledR}$ Non-Radioactive Cytotoxicity Assay, Promega) was used to evaluate the integrity of the cell membrane. The release of LDH into the culture medium indicates irreversible cell death due to cell membrane damage [42,43]. After treating the cells as mentioned above, $50 \mu \mathrm{L}$ of the supernatant was collected and tested according to the manufacturer's instructions. LDH leakage was calculated using the following equation. $\mathrm{LDH}_{\min }$ is the $\mathrm{LDH}$ leakage value of untreated cells. $\mathrm{LDH}_{\max }$ is the $\mathrm{LDH}$ leakage value of cells treated with $2 \%$ Triton-X100 (positive control) for $10 \mathrm{~min}$.

$$
\text { LDH leakage }(\% \text { of max LDH release })=\frac{(\text { LDHexp }- \text { LDHmin })}{(\text { LDHmax }- \text { LDHmin })} \times 100
$$

\subsection{Cell Cycle Analysis}

DNA fragmentation is a hallmark of apoptosis [44], and therefore, apoptotic cells eventually develop a deficit in DNA content. In DNA content histograms, apoptotic cells often form characteristic "sub-G1" or "hypodiploid" peaks [45-47]. HaCaT cells were seeded at a density of $2 \times 10^{5}$ cells/well in 6-well plates and incubated for $24 \mathrm{~h}$. After treatment, $\mathrm{HaCaT}$ cells were harvested and fixed in $70 \%(v / v)$ ethanol. To evaluate the DNA content, cells were treated with RNase and stained with propidium iodide. The cells were analyzed using a FACSVerse flow cytometer (BD Biosciences, San Jose, CA, USA). The data were analyzed using FlowJo (version X, BD Biosciences).

\subsection{Apoptosis Determination}

Cells were seeded at a density of $2 \times 10^{5}$ cells/well in 6-well plates and treated with $\mathrm{TiO}_{2}$ and UVA. The cells were incubated with $5 \mu \mathrm{L}$ of Annexin $\mathrm{V}$ and $5 \mu \mathrm{L}$ of propidium iodide (PI) for $15 \mathrm{~min}$ at room temperature in the dark, according to the manufacturer's instructions (BD), and then subjected to flow cytometry to measure the apoptosis rate (\%).

\subsection{Cell Lysates and Western Blotting}

$\mathrm{HaCaT}$ cells were seeded in $60 \mathrm{~mm}$ dishes and treated as mentioned above. The treated cells were scraped and harvested using PBS. After discarding the supernatant, the cell pellets were suspended in $2 \times$ Laemmli sample buffer with $5 \% \beta$-mercaptoethanol (Bio-Rad, Hercules, CA, USA), and boiled for $7 \mathrm{~min}$. The lysates were separated by $4-15 \%$ SDSPAGE and transferred onto an Immobilon membrane (Millipore, Burlington, MA, USA). In this study, the following primary antibodies were used: PARP1 (1:1000, ab32071, Abcam, Cambridge, UK) and $\beta$-actin (1:5000, \#3700, Cell Signaling Technology, Beverly, MA, USA). The secondary antibodies used were horseradish peroxidase (HRP)-conjugated goat antirabbit immunoglobulin $\mathrm{G}(\mathrm{IgG})$ and goat anti-mouse IgG (Invitrogen, Waltham, MA, USA). Bands were developed using the WesternBright ECL HRP substrate (Advansta, CA, USA). Quantification of the immunoblots was performed using Image J (NIH, MD, USA).

\subsection{Transmission Electron Microscopy}

The cells were prefixed in Karnovsky's solution (1\% paraformaldehyde, $2 \%$ glutaraldehyde, $2 \mathrm{mM}$ calcium chloride, and $0.1 \mathrm{M}$ cacodylate buffer, $\mathrm{pH}$ 7.4) for $2 \mathrm{~h}$ and washed with cacodylate buffer. Postfixing was carried out in 1\% osmium tetroxide and $1.5 \%$ potassium ferrocyanide for $1 \mathrm{~h}$. After dehydration with $50-100 \%$ alcohol, the cells were embedded in Poly/Bed 812 resin (Pelco, Redding, CA, USA), polymerized, and observed under an electron microscope (EM 902A; Carl Zeiss, Oberkochen, Germany).

\subsection{Lysosomal Integrity Assay}

As $\mathrm{AO}$ is a lysosomotropic dye that exhibits a red fluorescence under acidic conditions and green fluorescence in the non-acidic environment, therefore lysosomal acidification can be observed using the green/red fluorescence ratio in live cells [48]. We adopted the 
method described by Sun and Gan [49]. For fluorescence microscopy, HaCaT cells were seeded in 12-well plates and treated as mentioned above. After washing with PBS, the cells were stained with $5 \mu \mathrm{g} / \mathrm{mL}$ AO in DMEM for $15 \mathrm{~min}$ in the dark at $37^{\circ} \mathrm{C}$. Next, cells were washed with PBS again and further visualized using a fluorescence microscope (Leica Microsystems, Wetzlar, Germany). To quantitate fluorescence using a microplate reader, the cells were seeded in 96-well plates and allowed to attach to the plate for $24 \mathrm{~h}$. The cells were stained with $5 \mu \mathrm{g} / \mathrm{mL}$ AO for $15 \mathrm{~min}$. After washing with PBS, the cells were subsequently treated with $\mathrm{TiO}_{2} \mathrm{NPs}$ and subjected to UVA irradiation. The treated cells were incubated for $8 \mathrm{~h}$ and then washed with HBSS. Fluorescence was measured at an excitation wavelength of $485 \mathrm{~nm}$ and two emission wavelengths of 530 (green $\mathrm{AO}$ ) and $620 \mathrm{~nm}$ (red AO). Normal lysosomal integrity = total red fluorescence intensity of normal lysosomes / total green fluorescence intensity of normal lysosomes. Lysosomal integrity = total red fluorescence intensity / (total green fluorescence intensity $\times$ normal lysosomal integrity).

\subsection{Measurement of ROS}

When CM- $\mathrm{H}_{2}$ DCF-DA is oxidized by ROS such as $\mathrm{H}_{2} \mathrm{O}_{2}$ and free radicals, it can be detected by monitoring the increase in fluorescence [50]. The $\mathrm{TiO}_{2}$ treatment procedure is described above. The treated cells were loaded with $10 \mu \mathrm{M} \mathrm{CM}-\mathrm{H}_{2} \mathrm{DCF}-\mathrm{DA}$ for $30 \mathrm{~min}$ in the dark at $37^{\circ} \mathrm{C}$ and washed with HBSS. Fluorescence of the cells was measured using a microplate reader $\left(\lambda_{\mathrm{ex}}=495 \mathrm{~nm} / \lambda_{\mathrm{em}}=525 \mathrm{~nm}\right)$ and also observed by fluorescence microscopy.

\subsection{Inhibitor Study}

To investigate the relationship between LMP, ROS generation, and cell death, we used CA-074, a cathepsin B inhibitor, and NAC, a well-known antioxidant. When the medium was replaced after $\mathrm{TiO}_{2} \mathrm{NP}$ treatment and UVA irradiation, each inhibitor was added to the media prior to subsequent cell incubation.

\subsection{Statistical Analysis}

All data are presented as mean \pm standard error of the mean (SEM) or one standard deviation (SD) of at least three separate experiments. GraphPad Prism 7.0 software was used to perform statistical analyses. The normality of data was assessed using KolmogorovSmirnov test, and equal variance was assessed using Bartlett's test. For normally distributed data, statistical differences were determined using the analysis of variance, followed by Bonferroni's multiple comparison test. If the data were not normally distributed, KruskalWallis test was performed followed by Dunn's test.

\section{Results}

\subsection{Characterization of the $\mathrm{TiO}_{2}$ NP Suspension Employed for Cellular Exposure}

DLS was performed to determine the particle size distribution of the $\mathrm{TiO}_{2} \mathrm{NP}$ suspension (Figure 2). After dispersion in media, the z-average size of $\mathrm{TiO}_{2} \mathrm{NPs}$ was $209.7 \pm 2.9 \mathrm{~nm}$ (diameter, intensity weighted) with a polydispersity index of 0.246 (Figure 2a). In addition, the stability of the $\mathrm{TiO}_{2} \mathrm{NP}$ suspension during the test duration was tested. The particle size distribution profile was almost constant for 2 days (Figure $2 b$ ), indicating that the stability of the $\mathrm{TiO}_{2} \mathrm{NP}$ suspension was acceptable.

Since NP size distribution can undergo significant changes when transferred to environments used for biological studies [51], we characterized the dispersions of $\mathrm{TiO}_{2} \mathrm{NPs}$ in deionized water (DIW) and media by measuring size distributions and zeta potential values (Figure 2c). As expected, the z-average size of $\mathrm{TiO}_{2} \mathrm{NPs}$ was larger in the media $(209.7 \mathrm{~nm}$ ) than in DIW (157.1 nm) (Figure 2c). The zeta potential was $41.2 \mathrm{mV}$ in DIW and $-10.8 \mathrm{mV}$ in media (Figure 2c). These results suggest that the hydrodynamic size and zeta potential $\mathrm{TiO}_{2} \mathrm{NPs}$ both are affected due to the interaction with media components. 
(a)

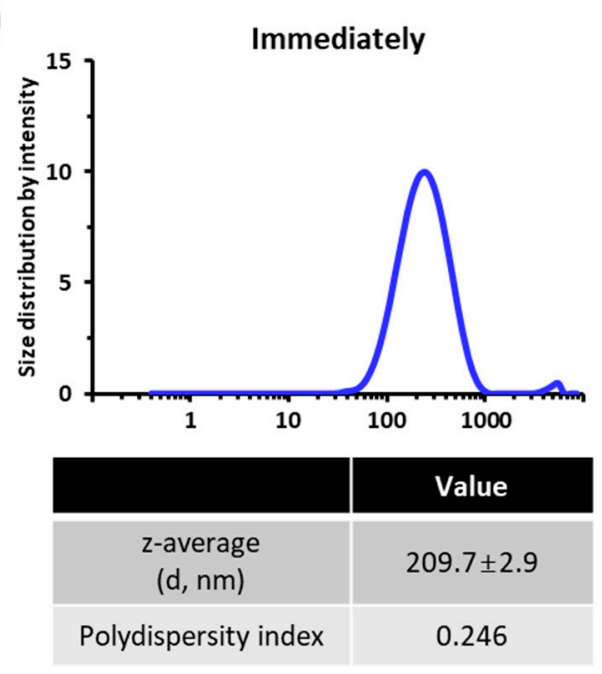

(b)

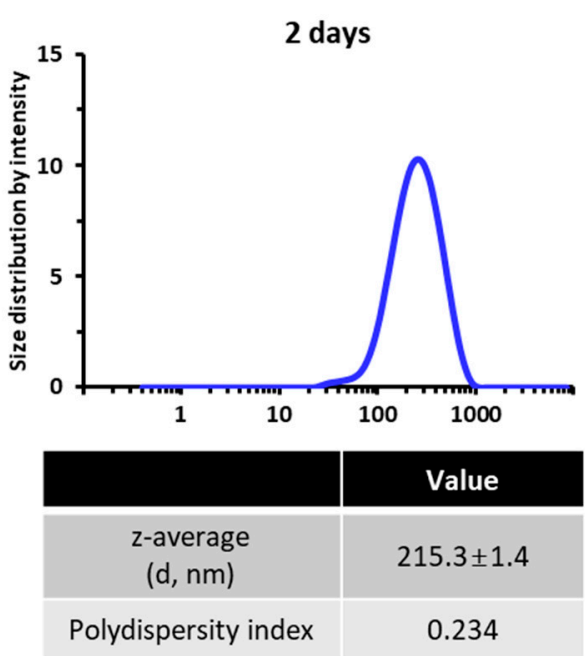

(c)

\begin{tabular}{|c|c|c|}
\hline & Media & DIW \\
\hline $\begin{array}{c}\text { z-average } \\
(\mathrm{d}, \mathrm{nm})\end{array}$ & 209.7 & 157.1 \\
\hline $\begin{array}{c}\text { Zeta potential } \\
(\mathrm{mV})\end{array}$ & -10.8 & 41.2 \\
\hline
\end{tabular}

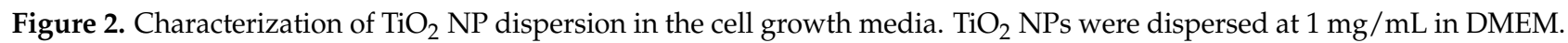
Size was measured by DLS immediately (a) and 2 days (b) after dispersion. (c) comparison $\mathrm{TiO}_{2} \mathrm{NPs}_{\text {dispersions in DIW }}$ and media. Size and zeta potential were measured immediately following the dispersion procedure.

\subsection{UVA Irradiation Induces Toxicity in $\mathrm{HaCaT}$ Cells Treated with $\mathrm{TiO}_{2} \mathrm{NPS}$}

The $3 \mathrm{~T} 3$ cell line is the most used cell line to study the effect of phototoxicity. These cells have several advantages, including availability, easy and inexpensive cultivation, as well as reproducibility. Recently, Svobodova et al. [52] reported that human keratinocyte $\mathrm{HaCaT}$ cells are also appropriate for in vitro phototoxicity testing. We have investigated how the viability of HaCaT cells is affected by a combined action of $\mathrm{TiO}_{2} \mathrm{NPs}$ exposure and UVA irradiation. Cell viability measurement demonstrated that $\mathrm{HaCaT}$ cells were largely unaffected to both $\mathrm{TiO}_{2}$ exposure (up to $200 \mu \mathrm{g} / \mathrm{mL}$ ) and UVA irradiation (up to $5 \mathrm{~J} / \mathrm{cm}^{2}$ ) treatment if applied separately (Figure 3a). However, the combination of $\mathrm{TiO}_{2}$ NPs and UVA irradiation markedly reduced the viability of HaCaT cells (Figure 3a). To quantify $\mathrm{TiO}_{2} \mathrm{NP}$ phototoxicity, we estimated the NP concentration at which $50 \%$ of cell growth $\left(\mathrm{IC}_{50}\right.$ value) is inhibited with and without UVA irradiation. The $\mathrm{IC}_{50}$ of the samples was reduced 10-fold with UVA irradiation, compared with that of nonirradiated samples (Figure 3a). To confirm cellular damage, we have performed the $\mathrm{LDH}$ assay. $\mathrm{TiO}_{2} \mathrm{NPs}$ alone at lower concentrations (up to $100 \mu \mathrm{g} / \mathrm{mL}$ ) did not induce a noticeable LDH release. However, the LDH activity was upregulated in cells that were subjected to the combined treatment with UVA compared to those treated with $\mathrm{TiO}_{2}$ NPs alone (Figure 3b). Taken together, these results clearly show that a combination of UVA irradiation and $\mathrm{TiO}_{2} \mathrm{NP}$ exposure significantly enhances the cytotoxicity. 
(a)

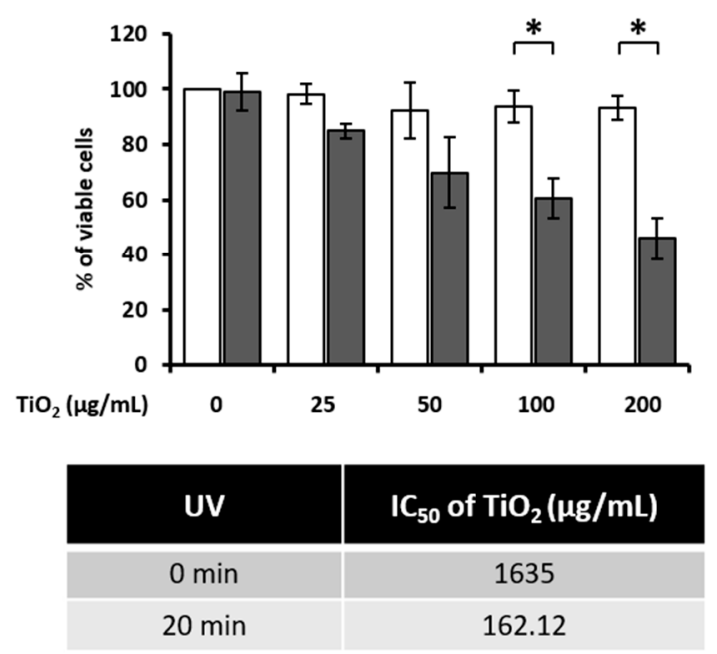

(b)

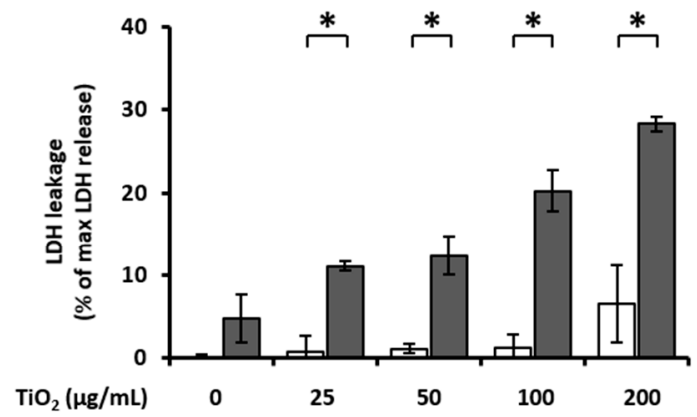

Figure 3. Effects of UVA exposure on $\mathrm{HaCaT}$ cells treated with $\mathrm{TiO}_{2} \mathrm{NPs}$ : (a) cellular viability was evaluated using the CellTiter-Glo ${ }^{\circledR}$ Luminescent cell viability assay; (b) lactate dehydrogenase (LDH) released by the cells was detected. Data are presented as mean $\pm \operatorname{SEM}(n=3) .{ }^{*} p<0.05$, compared with dark conditions.

\subsection{UVA Irradiation Facilitates the Apoptosis of $\mathrm{HaCaT}$ Cells Treated with $\mathrm{TiO}_{2} \mathrm{NPS}$}

Next, we examined the morphological changes in cells that occurred during the combined $\mathrm{TiO}_{2} \mathrm{NP}$ and UVA treatment. The cells treated with $\mathrm{TiO}_{2} \mathrm{NPs}$ or UVA irradiation alone remained attached to the substrate and largely retained their shape. In contrast, cells treated with both $\mathrm{TiO}_{2}$ NPs and UVA irradiation detached from the plate surface and became smaller and spherical (Figure 4a). Given that cell shrinkage, or cell volume loss, is often an indication of apoptosis [41], we verified whether the cell death induced by the combined treatment with $\mathrm{TiO}_{2} \mathrm{NPs}$ and UVA was apoptotic in nature. We examined the changes in DNA content following treatment with $\mathrm{TiO}_{2}$ NPs and UVA irradiation (Figure $4 \mathrm{~b}$ ). Only $12.7 \%$ of $\mathrm{HaCaT}$ cells treated with $\mathrm{TiO}_{2} \mathrm{NPs}$ alone for $24 \mathrm{~h}$ were in the sub-G1 phase, and there was no dramatic change in the DNA content, compared to the control group. However, treatment with both $\mathrm{TiO}_{2} \mathrm{NPs}$ and UVA increased the cell population in sub-G1 to $32.8 \%$. Simultaneously, G1, S, and G2/M populations were also smaller. Next, we detected the population of apoptotic cells using Annexin-V binding and PI staining. While the population of apoptotic cells $(\mathrm{Q} 2+\mathrm{Q} 4)$ did not change under treatment with $\mathrm{TiO}_{2}$ alone compared to the control group, it increased $6.6 \%$ after UVA irradiation alone. In addition, the combination treatment with $\mathrm{TiO}_{2} \mathrm{NPs}$ and UVA sharply increased the proportion of apoptotic cells to $26.9 \%$. These results provide further evidence that a combination of $\mathrm{TiO}_{2}$ and UVA leads to $\mathrm{HaCaT}$ cell death via the apoptotic pathway.

Since caspases are known as executioners in apoptosis [53], we also examined whether the $\mathrm{TiO}_{2} \mathrm{NP}$ and UVA-induced cell death was mediated by caspase activation. We found no evidence that poly (ADP-ribose) polymerase (PARP), a caspase substrate, was processed following the separate treatments of $\mathrm{HaCaT}$ cells with $\mathrm{TiO}_{2}$ NPs or UVA (Figure 4c). However, when both $\mathrm{TiO}_{2}$ NPs and UVA were applied, PARP was progressively processed (Figure 4c). To ascertain whether caspases are important in apoptosis induced by the combination of $\mathrm{TiO}_{2} \mathrm{NPs}$ and UVA, we investigated the effect of the pan-caspase inhibitor z-VAD-fmk on cell viability. The treatment of HaCaT cells with z-VAD-fmk blocked cotreatment-induced cell death in a dose-dependent manner (Figure 4d). Taken together, these results confirm that $\mathrm{TiO}_{2} \mathrm{NPs}$ under UVA irradiation induces the caspase-dependent apoptosis in $\mathrm{HaCaT}$ cells. 

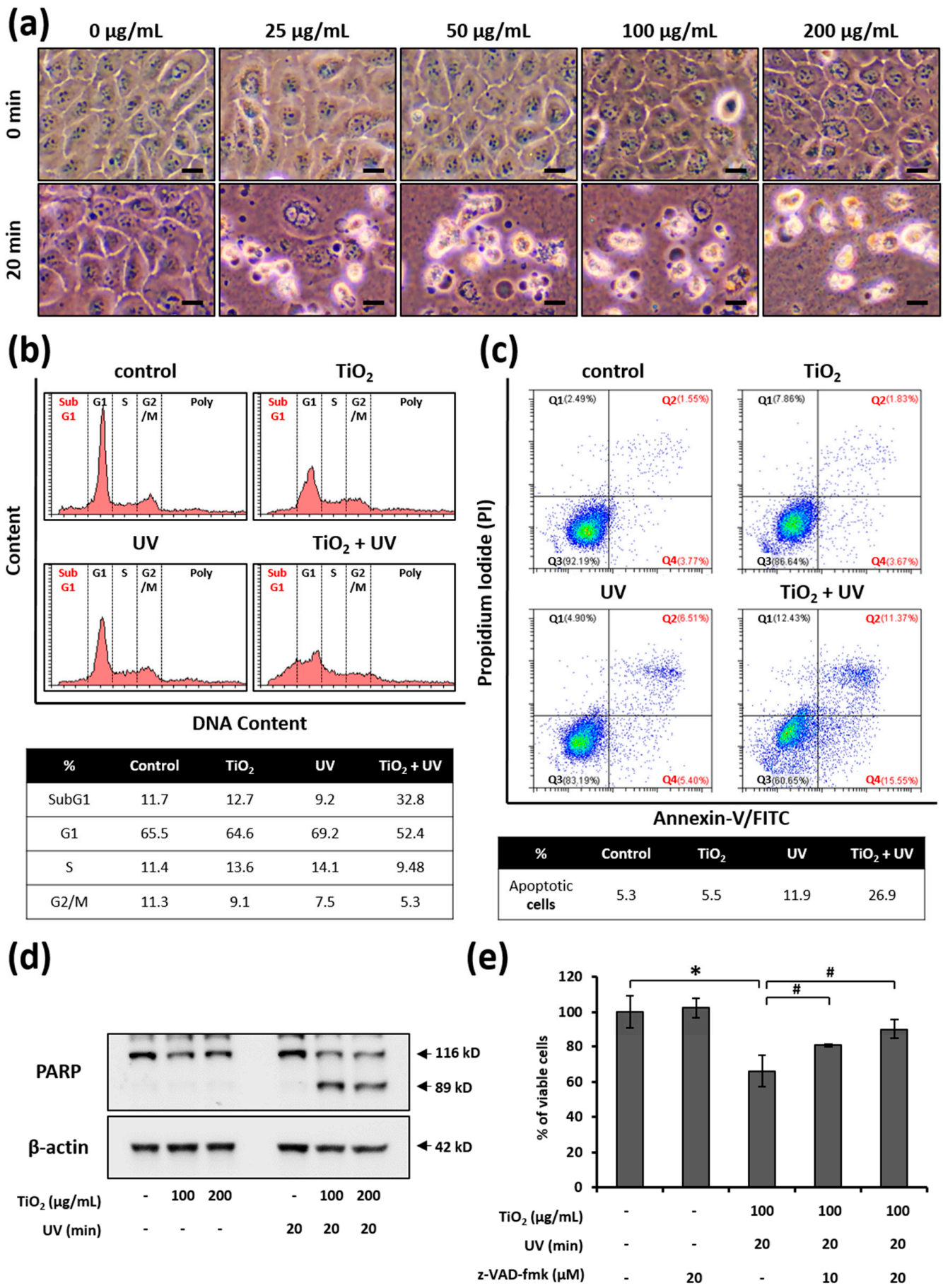

Figure 4. Apoptosis induction by the combination of $\mathrm{TiO}_{2} \mathrm{NPs}$ and UVA: (a) the treated cells were observed by bright-field microscopy. Scale bars correspond to $20 \mu \mathrm{m}$; (b) HaCaT cells were treated with a combination of $\mathrm{TiO}_{2} \mathrm{NPs}_{\text {and UVA. The }}$ DNA content was measured by flow cytometry after PI staining; (c) the treated cells were harvested and apoptosis was analyzed using the Annexin V-FITC Apoptosis Detection Kit by flow cytometry. The cells were classified as healthy cells (Q3; Annexin V-, PI-), early apoptotic cells (Q4; Annexin V+, PI-), late apoptotic cells (Q2; Annexin V+, PI+), and damaged cells (Q1; Annexin V-, PI+); (d) lysates were extracted from cells treated with $\mathrm{TiO}_{2} \mathrm{NPs}$ and/or UVA. Western blotting of PARP was performed. $\beta$-Actin was used as the loading control; (e) the cells were treated with $\mathrm{TiO}_{2} \mathrm{NPs}_{\text {for }} 24 \mathrm{~h}$ and subsequently irradiated with UVA for $20 \mathrm{~min}$. HBSS was replaced with the complete medium containing z-VAD-fmk, and the cells were incubated for $24 \mathrm{~h}$. Cellular viability was determined using the CellTiter-Glo ${ }^{\circledR}$ Luminescent cell viability assay. Data are presented as mean $\pm \operatorname{SEM}(n=3) .{ }^{*} p<0.05$, compared with the control; $\# p<0.05$, compared with the combination of $\mathrm{TiO}_{2}$ NPs and UVA. 


\section{4. $\mathrm{TiO}_{2} \mathrm{NPs}$ Accumulate in Lysosomes}

To observe the cellular uptake of $\mathrm{TiO}_{2} \mathrm{NPs}$ and structural changes in the cellular organelles in $\mathrm{TiO}_{2} \mathrm{NP}$ - and UVA-treated cells, we have employed electron microscopy (Figure 5). At first we have confirmed the cellular uptake of $\mathrm{TiO}_{2} \mathrm{NPs} . \mathrm{TiO}_{2} \mathrm{NPs}$ were not detected in untreated or only UVA-irradiated cells (Figure $5 \mathrm{a}, \mathrm{c}$ ). After treatment with $\mathrm{TiO}_{2} \mathrm{NPs}$ alone and in combination with $\mathrm{UVA}, \mathrm{TiO}_{2} \mathrm{NPs}$ aggregates were observed in phagosome-like structures (black arrowhead) but not in the nuclei (white arrow) or mitochondria (black arrow) (Figure 5b,d). Next, we observed alterations in the cellular organelle structures. The organelles did not substantially change except when treated with both $\mathrm{TiO}_{2} \mathrm{NPs}$ and UVA (Figure $5 \mathrm{a}, \mathrm{c}$ ). Remarkably, the mitochondrial structure remained almost unaltered in all of the imaged samples (Figure 5, black arrow). Moreover, we found that the combination of $\mathrm{TiO}_{2}$ NPs and UVA increased the number of phagosomal and lysosomal structures containing $\mathrm{TiO}_{2} \mathrm{NPs}$ (Figure $5 \mathrm{~d}$, black arrowhead). These membranes were noticeably ruptured (Figure $5 \mathrm{~d}$, white arrowhead).

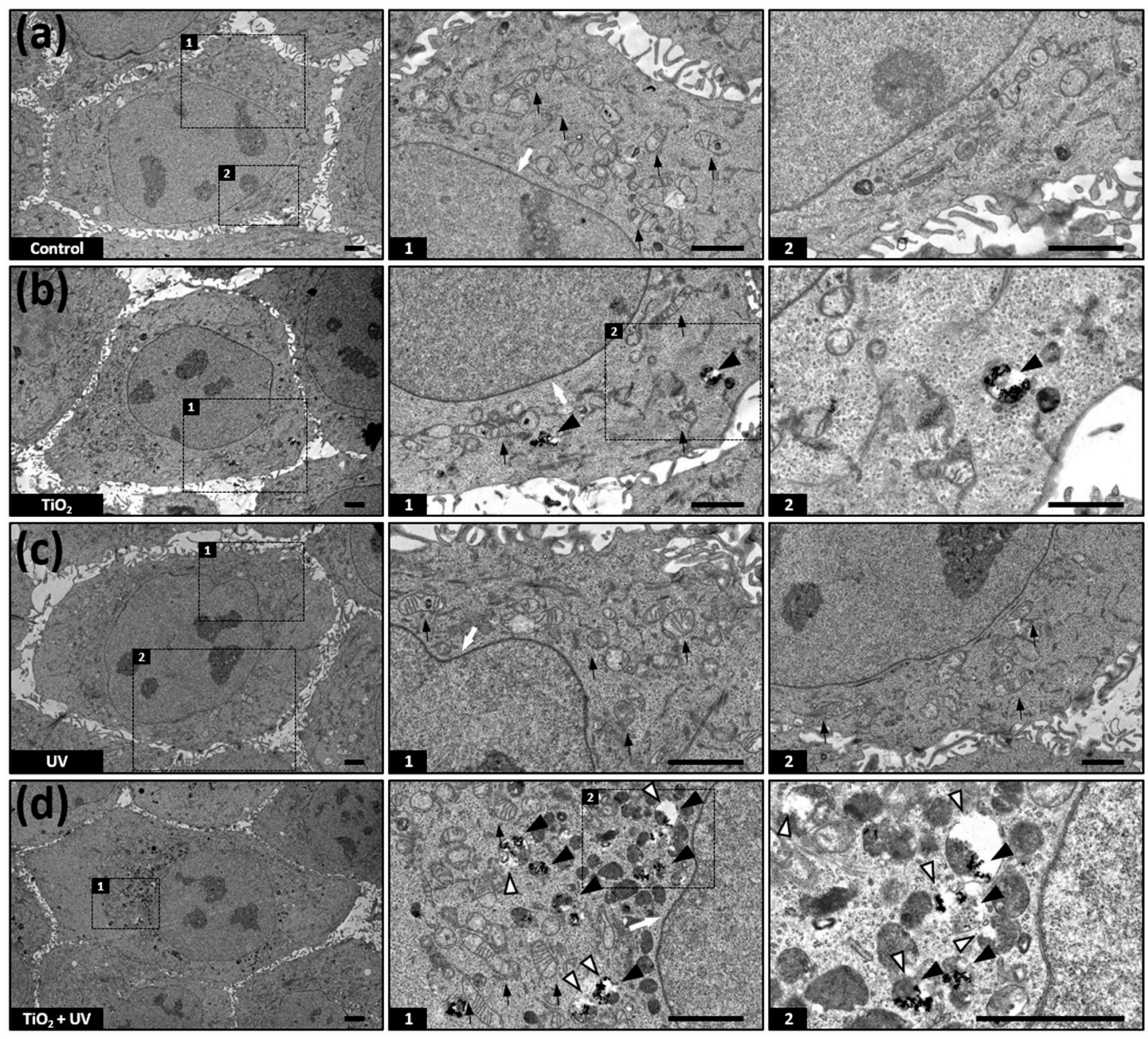

Figure 5. Transmission electron microscopy of HaCaT cells treated with $\mathrm{TiO}_{2} \mathrm{NPs}$ and UVA: (a) untreated cells; (b) cells treated with $\mathrm{TiO}_{2}$ NPs alone; (c) cells irradiated with UVA for $20 \mathrm{~min}$; (d) cells cotreated with $\mathrm{TiO}_{2} \mathrm{NPs}_{\text {and UVA. Scale bars }}$ correspond to $2 \mu \mathrm{m}$. Black arrowhead, phagosome-like structures; black arrow, mitochondria; white arrow, nuclei; white arrowhead, ruptured lysosome. 


\subsection{Combination of $\mathrm{TiO}_{2} \mathrm{NPS}$ and UVA Induces LMP}

As our results suggested that lysosomal membranes were altered by the combination of $\mathrm{TiO}_{2}$ NPs and UVA (e.g., ruptured membranes in Figure 5), we tested the lysosomal integrity of $\mathrm{HaCaT}$ cells by staining them with $\mathrm{AO}$. While red fluorescence was strong, green fluorescence was rather weak in the untreated cells. However, the cells treated with $\mathrm{TiO}_{2} \mathrm{NPs}$ and UVA mostly showed diminished red fluorescence and increased green fluorescence (Figure 6a), indicating that the lysosomes were severely damaged. Next, we quantified the lysosomal integrity using a microplate reader. The integrity of the lysosomes in cells treated with the combination of $\mathrm{TiO}_{2} \mathrm{NPs}$ and UVA decreased to $89.04 \pm 3.98 \%$ and $86.02 \pm 4.01 \%$ following the incubation with 100 and $200 \mu \mathrm{g} / \mathrm{mL} \mathrm{TiO}_{2} \mathrm{NPs}$, respectively, relative to lysosomes in untreated cells $(100 \%)$ (Figure $6 \mathrm{~b}$ ). These results suggest that lysosomal membranes are damaged during $\mathrm{HaCaT}$ cell death triggered by the combined treatment with $\mathrm{TiO}_{2}$ NPs and UVA.

(a)

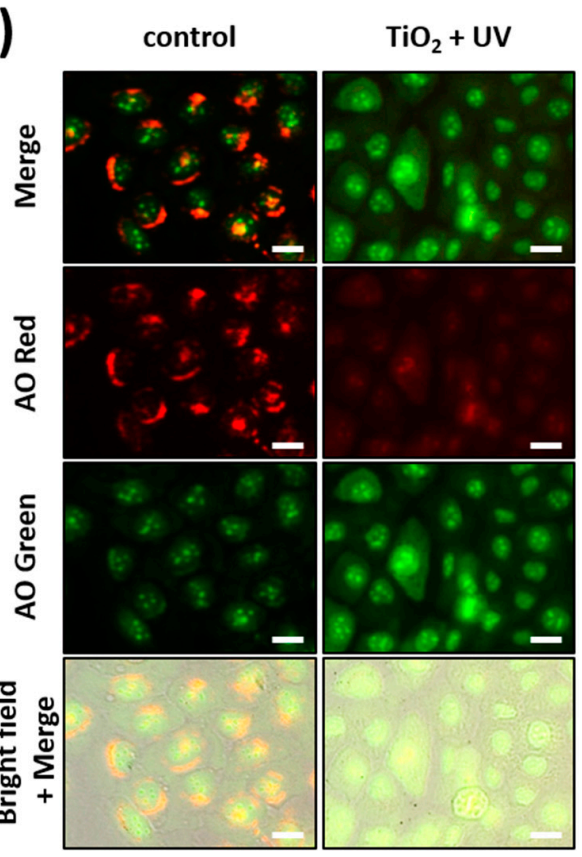

(c)

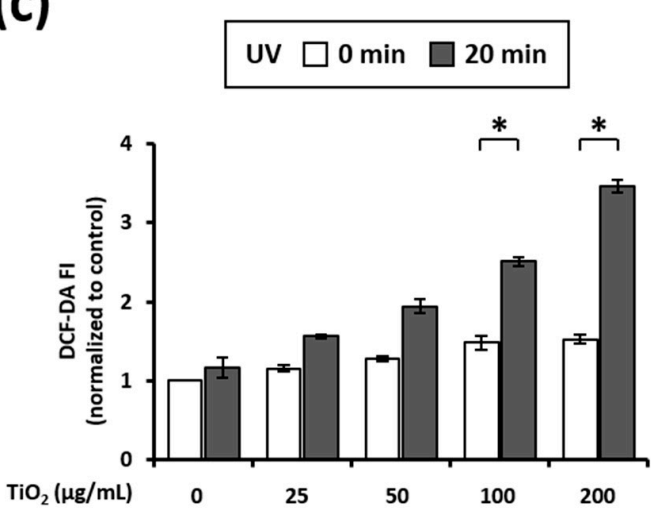

(b)

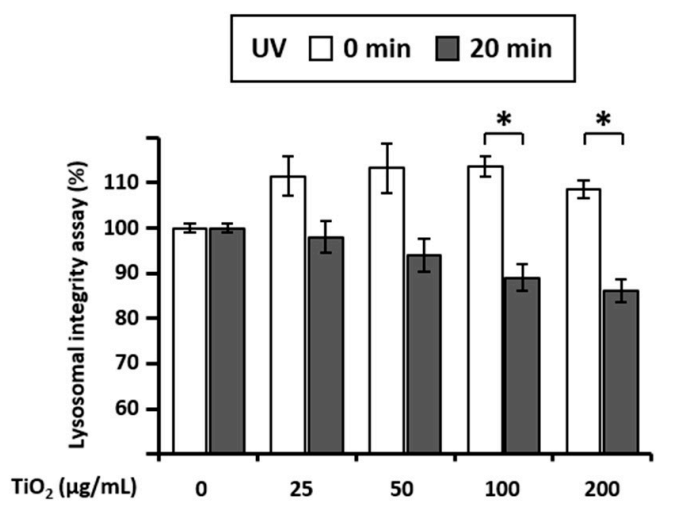

(d)

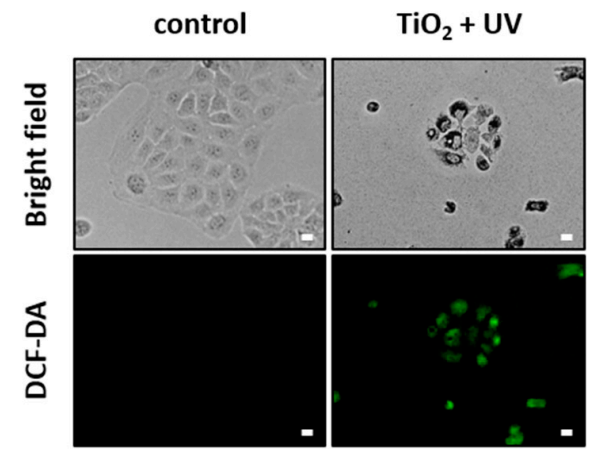

Figure 6. LMP induction and ROS generation by the combination of $\mathrm{TiO}_{2} \mathrm{NPs}$ and UVA: (a) the treated cells were stained with $\mathrm{AO}$ and then observed by fluorescence microscopy. Scale bars correspond to $10 \mu \mathrm{m}$; (b) after AO staining, the cells were treated with $\mathrm{TiO}_{2} \mathrm{NPs}$ and UVA for $8 \mathrm{~h}$. The cells were subjected to microplate reading. Data are presented as mean $\pm \mathrm{SD}$ $(n=8) .{ }^{*} p<0.05$, compared with dark conditions; $(\mathbf{c}, \mathbf{d})$ the treated cells were stained with CM- $\mathrm{H}_{2}$ DCF-DA. The cells were subjected to microplate reading: (c) data are presented as mean $\pm \operatorname{SD}(n=6) .{ }^{*} p<0.05$, compared with dark conditions; (d) cells were observed by fluorescence microscopy. Scale bars correspond to $20 \mu \mathrm{m}$. 


\subsection{Combination of $\mathrm{TiO}_{2} \mathrm{NPS}$ and UVA Induces ROS Generation}

The oxidative damage of cellular molecules caused by excessive ROS production is known as a major factor driving the phototoxicity of $\mathrm{TiO}_{2} \mathrm{NPs}$ [26-30]. In this study, we assayed intracellular ROS production using $\mathrm{CM}-\mathrm{H}_{2} \mathrm{DCF}-\mathrm{DA}$ dye. Independent treatment with $\mathrm{TiO}_{2}-\mathrm{NPs}$ and UVA generated rather low levels of intracellular ROS in a concentrationdependent manner (Figure 6c), whereas the combination of $\mathrm{TiO}_{2} \mathrm{NPs}$ and UVA significantly increased intracellular ROS. This was particularly noticeable in the cells treated with $200 \mu \mathrm{g} / \mathrm{mL} \mathrm{TiO}_{2} \mathrm{NPs}$, wherein, the intracellular ROS level increased by approximately 2.3 fold following treatment with UVA irradiation, compared with level in the non-irradiated sample (Figure 6c). Again, fluorescence microscopy images confirmed that $\mathrm{TiO}_{2}$ NPs and UVA noticeably boosted the ROS levels when combined (Figure 6d). These results confirm that intracellular ROS production accompanies $\mathrm{HaCaT}$ cell death caused by the combination of $\mathrm{TiO}_{2}$ NPs and UVA.

3.7. Relationship among LMP, ROS Generation, and Cell Death in $\mathrm{HaCaT}$ Cells Treated with $\mathrm{TiO}_{2}$ NPS and UVA

We examined the link between lysosomal membrane damage, ROS generation, and cell death induced by the combination of $\mathrm{TiO}_{2} \mathrm{NPs}$ and UVA. First, we assessed the role of the lysosomal membrane damage and ROS generation in cell death by means of CA-074, a cathepsin B inhibitor, and NAC, a well-known antioxidant. The treatment of $\mathrm{HaCaT}$ cells with CA-074 or NAC effectively inhibited the cell death, as caused by the combined treatment with $\mathrm{TiO}_{2}$ NPs and UVA (Figure 7a). This result implies that both lysosomal membrane damage and ROS generation are critical contributors to cell death under these conditions.

Next, we investigated the relationship between lysosomal membrane damage and ROS generation. ROS are known to induce LMP, especially when highly reactive hydroxyl radicals are produced in the lysosomes [54-56]. Therefore, we wanted to determine whether the loss of lysosomal membrane integrity occurs when ROS are produced in response to the combined $\mathrm{TiO}_{2} \mathrm{NPs}$ and UVA treatment. Unexpectedly, neither CA-074 nor NAC were effective in preserving the lysosomal membrane integrity in cells treated with $\mathrm{TiO}_{2} \mathrm{NPs}$ and UVA (Figure $7 \mathrm{~b}$ ). This result indicates that ROS increase was not the primary reason for the decline in lysosomal membrane integrity. Furthermore, as LMP may increase the generation of intracellular ROS via the release of free iron into the cytosol [57-59], we evaluated whether ROS can be generated due to LMP. Notably, both CA-074 and NAC attenuated ROS generation in response to the combined treatment with $\mathrm{TiO}_{2} \mathrm{NPs}_{\text {and UVA }}$ (Figure 7c). This result suggests that the loss of lysosomal membrane integrity is vital for $\mathrm{TiO}_{2} \mathrm{NP}$ and UVA-induced ROS generation. Taken together, these results show that the combination of $\mathrm{TiO}_{2} \mathrm{NPs}$ and UVA induces cell death via LMP-dependent ROS generation in $\mathrm{HaCaT}$ cells. 
(a)

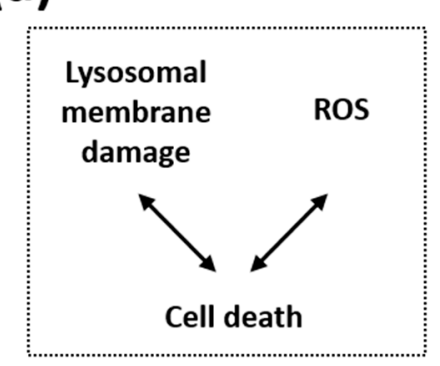

(b)

(c)

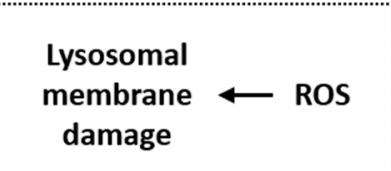

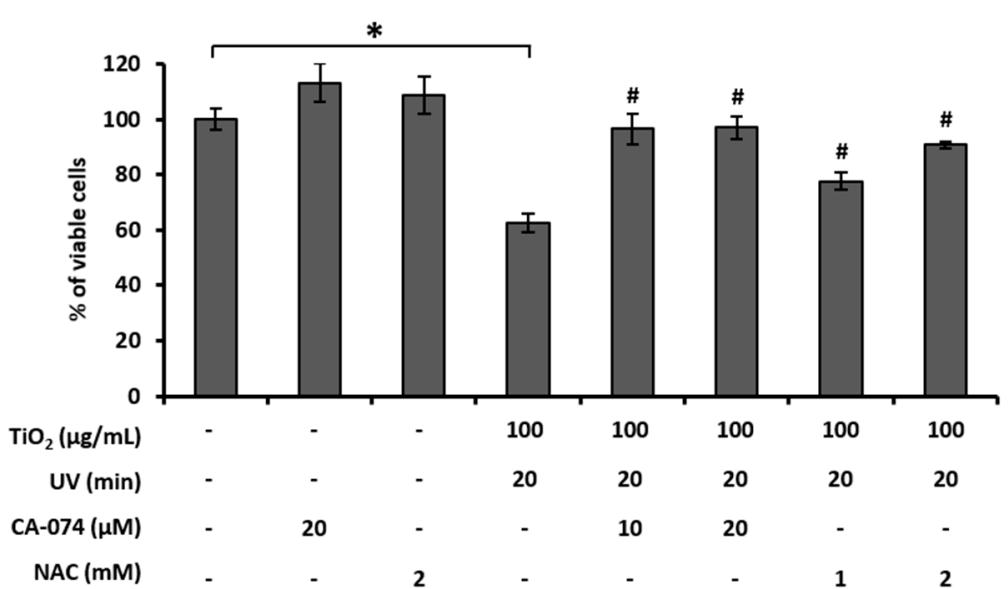
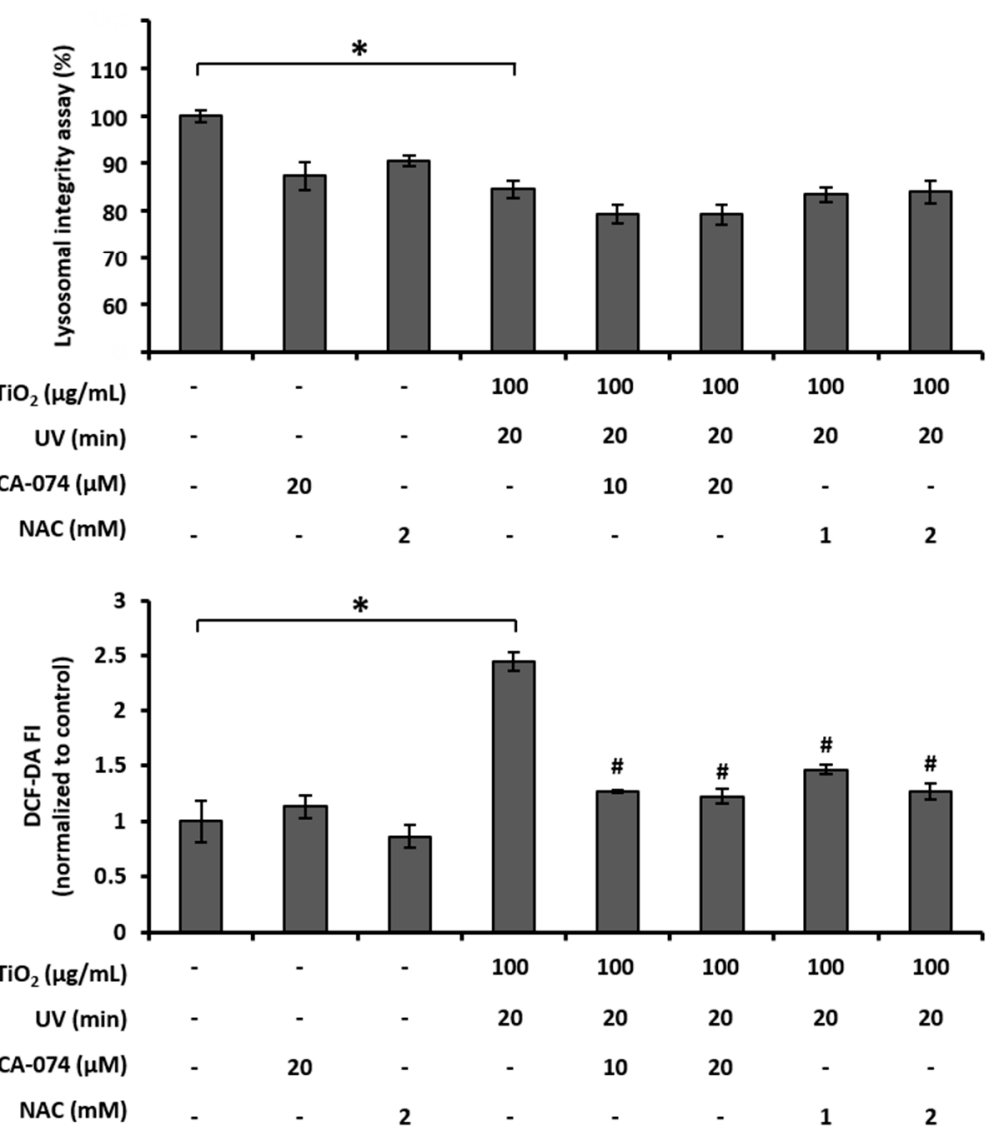

Figure 7. Interaction among cell death, LMP, and ROS in $\mathrm{HaCaT}$ cells treated with $\mathrm{TiO}_{2} \mathrm{NPs}$ and UVA: (a) the cells were treated with $\mathrm{TiO}_{2}$ NPs for $24 \mathrm{~h}$ and subsequently irradiated with UVA for $20 \mathrm{~min}$. HBSS was replaced with the complete medium containing CA-074 or NAC, and the cells were incubated for $24 \mathrm{~h}$. Cellular viability was evaluated using the CellTiter-Glo ${ }^{\circledR}$ Luminescent cell viability assay; (b) after AO staining, the cells were treated with $\mathrm{TiO}_{2} \mathrm{NPs}, \mathrm{UVA}$, and inhibitors for $8 \mathrm{~h}$. The cells were then subjected to microplate reading; (c) the treated cells were stained with CM- $\mathrm{H}_{2} \mathrm{DCF}-\mathrm{DA}$. The cells were subjected to microplate reading. Data are presented as mean $\pm \operatorname{SD}(n=8)$. ${ }^{*} p<0.05$, compared with untreated cells; \# $p<0.05$, compared with the combination of $\mathrm{TiO}_{2} \mathrm{NPs}_{\text {and UVA. }}$

\section{Discussion}

$\mathrm{TiO}_{2}$ NPs are among the most widely used nanomaterials in paints, plastics, cosmetics, and personal care products; they are also used as food additives and drug delivery agents $[60,61]$. They are widely used owing to their biocompatibility, high chemical stability, photocatalytic properties, and pronounced sensitivity to heat and magnetism [62-64]. The 
$\mathrm{TiO}_{2}$ NPs are being explored as potential candidates for degrading organic pollutants [65] and inactivating microorganisms owing to their photocatalytic activity $[60,66]$. However, these photocatalytic properties were reported to trigger oxidative damage, cellular structure destruction, key protein inactivation, and DNA damage, leading to cell apoptosis or necrosis [67-70]. To support their safe and efficient use, it is essential to identify mechanisms underlying the photocatalytic activity and phototoxicity of $\mathrm{TiO}_{2} \mathrm{NPs}$. In this study, we evaluated the phototoxicity of $\mathrm{TiO}_{2} \mathrm{NPs}$ on human skin keratinocytes subjected to UVA irradiation and investigated the mechanistic aspects of the resulting cell death.

As shown in Figure 3, $\mathrm{TiO}_{2}$ NPs exerted UVA-induced and dose-dependent toxicity in $\mathrm{HaCaT}$ cells. As cell viability decreases after $\mathrm{TiO}_{2} \mathrm{NP}$ and UVA treatment, we explored the mode of death of these cells. The photocatalytic activity of $\mathrm{TiO}_{2} \mathrm{NPs}$ can induce apoptosis and necrosis through various mechanisms [67,68,70-72]. Apoptosis is a form of programmed cell death characterized by caspase activation, cell contraction, apoptotic body formation, exposure outside the cell membrane, chromatin condensation, and DNA fragmentation [73-75]. Our data show that the DNA sub-G1 population increases following combined treatment with $\mathrm{TiO}_{2} \mathrm{NPs}$ and UVA (Figure $4 \mathrm{~b}$ ). In addition, PARP, a substrate of caspase-3, is cleaved and z-VAD-fmk, a pan-caspase inhibitor, increases the viability in $\mathrm{HaCaT}$ cells co-treated with $\mathrm{TiO}_{2} \mathrm{NPs}$ and UVA (Figure $4 \mathrm{c}, \mathrm{d}$ ). These results suggest that the $\mathrm{TiO}_{2} \mathrm{NPs}$ and UVA-induced cell death is caused by the caspase-dependent apoptosis.

We detected $\mathrm{TiO}_{2}$ NPs inside HaCaT cells using transmission electron microscopy; this confirmed that the phototoxicity observed in this study is induced by the intracellular accumulation of $\mathrm{TiO}_{2} \mathrm{NPs}$. Consistent with the results of Tucci et al. [76], $\mathrm{TiO}_{2} \mathrm{NPs}$ accumulated in the phagosomal and lysosomal structures of the cells but not in the nuclei or mitochondria (Figure 5b,d). Remarkably, we observed lysosomal membrane rupture in $\mathrm{HaCaT}$ cells treated with $\mathrm{TiO}_{2} \mathrm{NPs}$ and UVA (Figure $5 \mathrm{~d}$ ). The maintenance of lysosomal membrane integrity is vital for cell viability because ruptured lysosomal membranes induce the leakage of various digestive enzymes into the cytosol, resulting in membrane trafficking defects, abnormal energy metabolism, and cell death [77]. Recently, lysosomal damage has been suggested as a key mechanistic element of nanoparticle toxicity [78-80] because most endocytosed nanoparticles were found to accumulate in lysosomal compartments. In our study, we evaluated the lysosomal membrane integrity by AO staining and determined that combined treatment with $\mathrm{TiO}_{2}$ NPs and UVA damaged the lysosomal membranes in $\mathrm{HaCaT}$ cells (Figure 6a,b). In addition, CA-074, a cathepsin B inhibitor that protects against lysosomal rupture [81], prevented cell death induced by the combination of $\mathrm{TiO}_{2}$ NPs and UVA (Figure 7a). These results demonstrate that LMP is imperative for $\mathrm{TiO}_{2} \mathrm{NP}$ and UVA-induced cell death.

As ROS-mediated LMP is the prevailing mechanism [82], we examined the link between LMP and ROS generation when HaCaT cells are exposed to $\mathrm{TiO}_{2} \mathrm{NPs}$ and UVA. First, we found that $\mathrm{TiO}_{2}$ NPs subjected to UVA irradiation upregulated ROS generation in $\mathrm{HaCaT}$ cells (Figure 6c,d). In addition, the inhibition of ROS increased cell viability (Figure 7a), confirming the critical regulatory role of ROS in the progression of $\mathrm{HaCaT}$ cell apoptosis. Next, we tested lysosomal membrane integrity and ROS production in cells treated with the cathepsin B inhibitor CA-074 and antioxidant NAC. Interestingly, while CA-074 prevented ROS generation, NAC did not prevent the loss of lysosomal membrane integrity (Figure $7 \mathrm{~b}, \mathrm{c}$ ). Although several factors and chemicals have been reported to induce LMP and the associated cell death [83-85], it is not clear whether lysosomal leakage leads to oxidative stress during apoptotic cell death driven by the lysosomal pathway. Our study, for the first time, proves that lysosomal destabilization by $\mathrm{TiO}_{2} \mathrm{NPs}$ and UVA induces cellular ROS generation and oxidative stress.

Recent reports showed that besides $\mathrm{TiO}_{2}$ NPs other NPs, including $\mathrm{ZnO}, \mathrm{Au}$, and Ag NPs, exhibit photocatalytic activity [86]. In particular, the phototoxicity of ZnO NPs is studied because they are often included in paints, cosmetics, and medical materials, along with $\mathrm{TiO}_{2}$ NPs. Wang et al. [87] have reported that the phototoxicity of ZnO NPs under UVA and visible light irradiation is related to oxidative DNA damage. As ZnO 
NPs and $\mathrm{TiO}_{2}$ have comparable bandgap energy $(3.2 \mathrm{eV})$ and photocatalytic activity [88], they can be expected to cause a similar cellular toxicity. However, the important difference between these two materials is their chemical stability, as $\mathrm{ZnO}$ slowly dissolves under UV illumination, releasing metal ions, while $\mathrm{TiO}_{2}$ is chemically stable.

\section{Conclusions}

Previous studies have shown that ROS generation is the primary cause of the phototoxicity in cells treated with $\mathrm{TiO}_{2}$ under UVA irradiation. In this study, we examined the mechanism underlying the phototoxicity induced by $\mathrm{TiO}_{2}$ in $\mathrm{HaCaT}$ cells. We present evidence that $\mathrm{TiO}_{2}$ induces lysosomal membrane damage and subsequently stimulates ROS production. We focused on the effects of $\mathrm{TiO}_{2} \mathrm{NP}$ uptake and UVA sensitization on lysosomal membrane integrity in $\mathrm{HaCaT}$ cells. We found that major lysosomal destabilization occurs when accumulated $\mathrm{TiO}_{2} \mathrm{NPs}$ are photoexcited by UVA. Consequently, the loss of lysosomal membrane integrity is essential for $\mathrm{TiO}_{2}$ NPs and UVA-induced ROS surge. Taken together, our findings strongly suggest that caspase-dependent apoptosis is a key mechanism underlying $\mathrm{HaCaT}$ cell death, induced by their exposure to photoexcited $\mathrm{TiO}_{2}$ NPs.

Certain instruments and materials are identified in this paper to adequately specify experimental details. In no case does it imply endorsement by NIST or that it is necessarily the best product for the experimental procedure.

Author Contributions: Conceptualization, I.Y.K., T.G.L. and M.-B.H.; methodology, I.Y.K. and M.B.H.; validation, I.Y.K. and M.B.H.; writing—original draft preparation, I.Y.K., V.R. and M.B.H.; writing - review and editing, I.Y.K., V.R. and M.B.H.; project administration, M.B.H.; funding acquisition, T.G.L. and M.B.H. All authors have read and agreed to the published version of the manuscript.

Funding: This research was supported by the Nano Material Technology Development Program, [Grant Number 2016M3A7B6908929] of the National Research Foundation (NRF) of Korea funded by the Ministry of Science and ICT (MSIT), Development of Measurement Standards and Technology for Biomaterials and Medical Convergence funded by the Korea Research Institute of Standards and Science [KRISS -R2021 -GP2021-0004] and the Industrial Strategic Technology Development Program [20009773, Commercialization of 3D Multifunction Tissue Mimetics Based Drug Evaluation Platform] funded by the Ministry of Trade, Industry, and Energy (MOTIE, Korea).

Data Availability Statement: All data are contained within the article.

Conflicts of Interest: The authors declare no conflict of interest.

\section{References}

1. Ferin, J.; Oberdorster, G.; Penney, D.P.; Soderholm, S.C.; Gelein, R.; Piper, H.C. Increased pulmonary toxicity of ultrafine particles? I. Particle clearance, translocation, morphology. J. Aerosol Sci. 1990, 21, 381-384. [CrossRef]

2. Schulte, P.A.; Leso, V.; Niang, M.; Iavicoli, I. Current state of knowledge on the health effects of engineered nanomaterials in workers: A systematic review of human studies and epidemiological investigations. Scand. J. Work Environ. Health 2019, 45, 217-238. [CrossRef]

3. Yordanov, Y.I.; Tzankova, V.I.; Yoncheva, K. Nanotoxicology: Factors, affecting toxicity. Pharmacia 2018, 65, 63-71. Available online: https:/ / www.academia.edu/40211413/Nanotoxicology_Factors_affecting_toxicity (accessed on 27 July 2021).

4. Xiong, S.; Tang, Y.; Ng, H.S.; Zhao, X.; Jiang, Z.; Chen, Z.; Ng, K.W.; Loo, S.C.J. Specific surface area of titanium dioxide (TiO 2 ) particles influences cyto- and photo-toxicity. Toxicology 2013, 304, 132-140. [CrossRef]

5. Peters, K.; Unger, R.E.; Kirkpatrick, C.J.; Gatti, A.M.; Monari, E. Effects of nano-scaled particles on endothelial cell function in vitro: Studies on viability, proliferation and inflammation. J. Mater. Sci. Mater. Med. 2004, 15, 321-325. [CrossRef] [PubMed]

6. Yamamoto, A.; Honma, R.; Sumita, M.; Hanawa, T. Cytotoxicity evaluation of ceramic particles of different sizes and shapes. J. Biomed. Mater. Res. A 2004, 68, 244-256. [CrossRef] [PubMed]

7. Zhang, Q.; Kusaka, Y.; Sato, K.; Nakakuki, K.; Kohyama, N.; Donaldson, K. Differences in the extent of inflammation caused by intratracheal exposure to three ultrafine metals: Role of free radicals. J. Toxicol. Environ. Health A 1998, 53, 423-438. [CrossRef]

8. Pippins, R.; Samson, A.J.; Trentacost, E. FDA, State, and Local Governments Act to Modernize the Regulation of Sunscreen Products in the United States. Available online: https:/ /www.arnoldporter.com/en/perspectives/publications/2019/03/fdastate-and-local-governments-act-to-modernize (accessed on 27 July 2021).

9. Erickson, B.E. Titanium dioxide unsafe in food, EU panel says. Chem. Eng. News 2021, 99. Available online: https://cen.acs.org/ food/food-ingredients/Titanium-dioxide-unsafe-food-EU/99/i18 (accessed on 27 July 2021). 
10. Carinci, F.; Volinia, S.; Pezzetti, F.; Francioso, F.; Tosi, L.; Piattelli, A. Titanium-cell interaction: Analysis of gene expression profiling. J. Biomed. Mater. Res. B Appl. Biomater. 2003, 66, 341-346. [CrossRef]

11. Gurr, J.; Wang, A.S.S.; Chen, C.; Jan, K. Ultrafine titanium dioxide particles in the absence of photoactivation can induce oxidative damage to human bronchial epithelial cells. Toxicology 2005, 213, 66-73. [CrossRef]

12. Long, T.C.; Saleh, N.; Tilton, R.D.; Lowry, G.V.; Veronesi, B. Titanium dioxide (P25) produces reactive oxygen species in immortalized brain microglia (BV2): Implications for nanoparticle neurotoxicity. Environ. Sci. Technol. 2006, 40, 4346-4352. [CrossRef] [PubMed]

13. Rahman, Q.; Lohani, M.; Dopp, E.; Pemsel, H.; Jonas, L.; Weiss, D.G.; Schiffmann, D. Evidence that ultrafine titanium dioxide induces micronuclei and apoptosis in Syrian hamster embryo fibroblasts. Environ. Health Perspect. 2002, 110, 797-800. [CrossRef]

14. Wang, F.; Salvati, A.; Boya, P. Lysosome-dependent cell death and deregulated autophagy induced by amine-modified polystyrene nanoparticles. Open Biol. 2018, 8, 170271. [CrossRef] [PubMed]

15. Kroemer, G.; Jäättelä, M. Lysosomes and autophagy in cell death control. Nat. Rev. Cancer 2005, 5, 886-987. [CrossRef]

16. Guicciardi, M.E.; Leist, M.; Gores, G.J. Lysosomes in cell death. Oncogene 2004, 23, 2881-2890. [CrossRef]

17. Popp, L.; Tran, V.; Patel, R.; Segatori, L. Autophagic response to cellular exposure to titanium dioxide nanoparticles. Acta Biomater. 2018, 79, 354-363. [CrossRef]

18. Yu, Q.; Wang, H.; Peng, Q.; Li, Y.; Liu, Z.; Li, M. Different toxicity of anatase and rutile $\mathrm{TiO}_{2}$ nanoparticles on macrophages: Involvement of difference in affinity to proteins and phospholipids. J. Hazard Mater. 2017, 335, 125-134. [CrossRef] [PubMed]

19. Jovanovic, B. Review of titanium dioxide nanoparticle phototoxicity: Developing a phototoxicity ratio to correct the endpoint values of toxicity tests. Environ. Toxicol. Chem. 2015, 34, 1070-1077. [CrossRef] [PubMed]

20. Park, H.; Yu, M.; Kang, S.K.; Yang, S.I.; Kim, Y.J. Comparison of cellular effects of titanium dioxide nanoparticles with different photocatalytic potential in human keratinocyte, HaCaT cells. Mol. Cell Toxicol. 2011, 7, 67-75. [CrossRef]

21. Dasari, T.P.; Pathakoti, K.; Hwang, H.M. Determination of the mechanism of photoinduced toxicity of selected metal oxide nanoparticles $\left(\mathrm{ZnO}, \mathrm{CuO}, \mathrm{Co}_{3} \mathrm{O}_{4}\right.$ and $\left.\mathrm{TiO}_{2}\right)$ to E. coli bacteria. J. Environ. Sci. 2013, 25, 882-888. [CrossRef]

22. Petersen, E.J.; Reipa, V.; Watson, S.S.; Stanley, D.L.; Rabb, S.A.; Nelson, B.C. DNA damaging potential of photoactivated p25 titanium dioxide nanoparticles. Chem. Res. Toxicol. 2014, 27, 1877-1884. [CrossRef]

23. OPINION ON Titanium Dioxide (Nano Form) COLIPA No S75; Scientific Committee on Consumer Safety (SCCS), European Commission: Luxembourg, 2018. [CrossRef]

24. Agrios, A.G.; Pichat, P. State of the art and perspectives on materials and applications of photocatalysis over $\mathrm{TiO}_{2}$. J. Appl. Electrochem. 2005, 35, 655-663. [CrossRef]

25. Herrmann, J.M. Heterogeneous photocatalysis: Fundamentals and applications to the removal of various types of aqueous pollutants. Catal. Today 1999, 53, 115-129. [CrossRef]

26. Horie, M.; Sugino, S.; Kato, H.; Tabei, Y.; Nakamura, A.; Yoshida, Y. Does photocatalytic activity of $\mathrm{TiO}_{2}$ nanoparticles correspond to photo-cytotoxicity? Cellular uptake of $\mathrm{TiO}_{2}$ nanoparticles is important in their photo-cytotoxicity. Toxicol. Mech. Methods 2016, 26, 284-294. [CrossRef] [PubMed]

27. Seo, J.W.; Chung, H.; Kim, M.Y.; Lee, J.; Choi, I.H.; Cheon, J. Development of water-soluble single-crystalline TiO 2 nanoparticles for photocatalytic cancer-cell treatment. Small 2007, 3, 850-853. [CrossRef]

28. Wang, C.; Cao, S.; Tie, X.; Qiu, B.; Wu, A.; Zheng, Z. Induction of cytotoxicity by photoexcitation of $\mathrm{TiO}_{2}$ can prolong survival in glioma-bearing mice. Mol. Biol. Rep. 2011, 38, 523-530. [CrossRef]

29. Xue, C.; Luo, W.; Yang, X.L. A mechanism for nano-titanium dioxide-induced cytotoxicity in HaCaT cells under UVA irradiation. Biosci. Biotechnol. Biochem. 2015, 79, 1384-1390. [CrossRef] [PubMed]

30. Yin, J.J.; Liu, J.; Ehrenshaft, M.; Roberts, J.E.; Fu, P.P.; Mason, R.P.; Zhao, B. Phototoxicity of nano titanium dioxides in HaCaT keratinocytes-Generation of reactive oxygen species and cell damage. Toxicol. Appl. Pharmacol. 2012, 263, 81-88. [CrossRef] [PubMed]

31. Zhang, A.P.; Sun, Y.P. Photocatalytic killing effect of $\mathrm{TiO}_{2}$ nanoparticles on Ls-174-t human colon carcinoma cells. World J. Gastroenterol. 2004, 10, 3191-3193. [CrossRef] [PubMed]

32. Gomes, S.I.L.; Roca, C.P.; von der Kammer, F.; Scott-Fordsmand, J.J.; Amorim, M.J.B. Mechanisms of (photo)toxicity of TiO 2 nanomaterials (NM103, NM104, NM105): Using high-throughput gene expression in Enchytaraeus crypticus. Nanoscale 2018, 10, 21960-21970. [CrossRef]

33. Kang, S.J.; Lee, Y.J.; Kim, B.M.; Choi, Y.J.; Chung, H.W. Cytotoxicity and genotoxicity of titanium dioxide nanoparticles in UVA-irradiated normal peripheral blood lymphocytes. Drug Chem. Toxicol. 2011, 34, 277-284. [CrossRef] [PubMed]

34. Kessel, D.; Reiners, J.J., Jr. Apoptosis and autophagy after mitochondrial or endoplasmic reticulum photodamage. Photochem. Photobiol. 2007, 83, 1024-1028. [CrossRef] [PubMed]

35. Yu, K.N.; Chang, S.H.; Park, S.J.; Lim, J.; Lee, J.; Yoon, T.J.; Kim, K.S.; Cho, M.H. Titanium dioxide nanoparticles induced endoplasmic reticulum stress-mediated autophagic cell death via mitochondria-associated endoplasmic reticulum membrane disruption in normal lung cells. PLoS ONE 2015, 10, e0131208. [CrossRef]

36. Xue, C.; Li, X.; Liu, G.; Liu, W. Evaluation of mitochondrial respirator chain on the generation of reactive oxygen species and cytotoxicity in HaCaT cells induced by nanosized titanium dioxide under UVA irradiation. Int. J. Toxicol. 2016, 35, 644-653. [CrossRef] 
37. Bivik, C.A.; Larsson, P.K.; Kågedal, K.M.; Rosdahl, I.K.; Ollinger, K.M. UVA/B-induced apoptosis in human melanocytes involves translocation of cathepsins and Bcl-2 family members. J. Investig. Dermatol. 2006, 126, 1119-1127. [CrossRef] [PubMed]

38. Bivik, C.; Rosdahl, I.; Ollinger, K. Hsp70 protects against UVB induced apoptosis by preventing release of cathepsins and cytochrome c in human melanocytes. Carcinogenesis 2007, 28, 537-544. [CrossRef] [PubMed]

39. Mohammadalipour, Z.; Rahmati, M.; Khataee, A.; Moosavi, M.A. Differential effects of N-TiO 2 nanoparticle and its photoactivated form on autophagy and necroptosis in human melanoma A375 cells. J. Cell. Physiol. 2020, 235, 8246-8259. [CrossRef]

40. Stern, S.T.; Adiseshaiah, P.P.; Crist, R.M. Autophagy and lysosomal dysfunction as emerging mechanisms of nanomaterial toxicity. Part Fibre Toxicol. 2012, 9, 20. [CrossRef]

41. Taurozzi, J.S.; Hackley, V.A.; Wiesner, M.R. Preparation of nanoscale $\mathrm{TiO}_{2}$ dispersion in biological test media for toxicological assessment. NIST Spec. Publ. 2012, 1200. [CrossRef]

42. Akhtar, M.J.; Ahamed, M.; Alhadlaq, H. Gadolinium oxide nanoparticles induce toxicity in human endothelial HUVECs via lipid peroxidation, mitochondrial dysfunction and autophagy modulation. Nanomaterials 2020, 10, 1675. [CrossRef]

43. Fotakis, G.; Timbrell, J.A. In vitro cytotoxicity assays: Comparison of LDH, neutral red, MTT and protein assay in hepatoma cell lines following exposure to cadmium chloride. Toxicol. Lett. 2006, 160, 171-177. [CrossRef] [PubMed]

44. Kerr, J.F.; Wyllie, A.H.; Currie, A.R. Apoptosis: A basic biological phenomenon with wide-ranging implications in tissue kinetics. Br. J. Cancer 1972, 26, 239-257. [CrossRef]

45. Gong, J.; Traganos, F.; Darzynkiewicz, Z. A selective procedure for DNA extraction from apoptotic cells applicable for gel electrophoresis and flow cytometry. Anal. Biochem. 1994, 218, 314-319. [CrossRef] [PubMed]

46. Nicoletti, I.; Migliorati, G.; Pagliacci, M.C.; Grignani, F.; Riccardi, C. A rapid and simple method for measuring thymocyte apoptosis by propidium iodide staining and flow cytometry. J. Immunol. Methods 1991, 139, 271-279. [CrossRef]

47. Umansky, S.R.; Korol', B.A.; Nelipovich, P.A. In vivo DNA degradation in the thymocytes of gamma-irradiated or hydrocortisonetreated rats. Biochim. Biophys. Acta 1981, 655, 9-17. [CrossRef]

48. Han, J.; Burgess, K. Fluorescent indicators for intracellular pH. Chem. Rev. 2010, 110, 2709-2728. [CrossRef] [PubMed]

49. Sun, X.Y.; Gan, Q.Z.; Ouyang, J.M. Size-dependent cellular uptake mechanism and cytotoxicity toward calcium oxalate on Vero cells. Sci. Rep. 2017, 7, 41949. [CrossRef]

50. Kirkland, R.A.; Saavedra, G.M.; Franklin, J.L. Rapid activation of antioxidant defenses by nerve growth factor suppresses reactive oxygen species during neuronal apoptosis: Evidence for a role in cytochrome c redistribution. J. Neurosci. 2007, 27, 11315-11326. [CrossRef] [PubMed]

51. Mailänder, V.; Landfester, K. Interaction of nanoparticles with cells. Biomacromolecules 2009, 10, 2379-2400. [CrossRef]

52. Svbodova, A.R.; Ulrichova, J.; Vostalove, J. Human keratinocyte cell lines as a suitable alternative model for in vitro phototoxicity testing. An. Bras. Dematol. 2019, 94, 105-106. [CrossRef]

53. Shi, Y. Caspase activation, inhibition, and reactivation: A mechanistic view. Protein Sci. 2004, 13, 1979-1987. [CrossRef]

54. Aits, S.; Jäättelä, M. Lysosomal cell death at a glance. J. Cell Sci. 2013, 126, 1905-1912. [CrossRef] [PubMed]

55. Česen, M.H.; Pegan, K.; Spes, A.; Turk, B. Lysosomal pathways to cell death and their therapeutic applications. Exp. Cell Res. 2012, 318, 1245-1251. [CrossRef]

56. Serrano-Puebla, A.; Boya, P. Lysosomal membrane permeabilization in cell death: New evidence and implications for health and disease. Ann. N. Y. Acad. Sci. 2016, 1371, 30-44. [CrossRef] [PubMed]

57. Kon, K.; Kim, J.S.; Jaeschke, H.; Lemasters, J.J. Mitochondrial permeability transition in acetaminophen-induced necrosis and apoptosis of cultured mouse hepatocytes. Hepatology 2004, 40, 1170-1179. [CrossRef]

58. Persson, H.J.; Yu, Z.; Tirosh, O.; Eaton, J.W.; Brunk, U.T. Prevention of oxidant-induced cell death by lysosomotropic iron chelators. Free Radic. Biol. Med. 2003, 34, 1295-1305. [CrossRef]

59. Uchiyama, A.; Kim, J.S.; Kon, K.; Jaeschke, H.; Ikejima, K.; Watanabe, S.; Lemasters, J. Translocation of iron from lysosomes into mitochondria is a key event during oxidative stress-induced hepatocellular injury. Hepatology 2008, 48, 1644-1654. [CrossRef]

60. Kangwansupamonkon, W.; Lauruengtana, V.; Surassmo, S.; Ruktanonchai, U. Antibacterial effect of apatite-coated titanium dioxide for textiles applications. Nanomedicine 2009, 5, 240-249. [CrossRef]

61. Ray, P.C.; Yu, H.; Fu, P.P. Toxicity and environmental risks of nanomaterials: Challenges and future needs. J. Environ. Sci. Health C Environ. Carcinog. Ecotoxicol. Rev. 2009, 27, 1-35. [CrossRef] [PubMed]

62. Dudefoi, W.; Moniz, K.; Allen-Vercoe, E.; Ropers, M.H.; Walker, V.K. Impact of food grade and nano-TiO 2 particles on a human intestinal community. Food Chem. Toxicol. 2017, 106, 242-249. [CrossRef] [PubMed]

63. Jo, M.R.; Yu, J.; Kim, H.J.; Song, J.H.; Kim, K.M.; Oh, J.M.; Choi, S.J. Titanium dioxide nanoparticle-biomolecule interactions influence oral absorption. Nanomaterials 2016, 6, 225. [CrossRef]

64. Saber, A.T.; Jacobsen, N.R.; Mortensen, A.; Szarek, J.; Jackson, P.; Madsen, A.M.; Jensen, K.A.; Koponen, I.K.; Brunborg, G.; Gutzkow, K.B.; et al. Nanotitanium dioxide toxicity in mouse lung is reduced in sanding dust from paint. Part Fibre Toxicol. 2012, 9, 4. [CrossRef]

65. Mura, G.M.; Ganadu, M.L.; Lubinu, G.; Maida, V. Photodegradation of organic waste coupling hydrogenase and titanium dioxide. Ann. N. Y. Acad. Sci. 1999, 879, 267-275. [CrossRef] [PubMed]

66. Foster, H.A.; Ditta, I.B.; Varghese, S.; Steele, A. Photocatalytic disinfection using titanium dioxide: Spectrum and mechanism of antimicrobial activity. Appl. Microbiol. Biotechnol. 2011, 90, 1847-1868. [CrossRef] [PubMed] 
67. Baines, C.P.; Kaiser, R.A.; Purcell, N.H.; Blair, N.S.; Osinska, H.; Hambleton, M.A.; Brunskill, E.W.; Sayen, M.R.; Gottlieb, R.A.; Dorn, G.W.; et al. Loss of cyclophilin D reveals a critical role for mitochondrial permeability transition in cell death. Nature 2005, 434, 658-662. [CrossRef] [PubMed]

68. Braydich-Stolle, L.K.; Schaeublin, N.M.; Murdock, R.C.; Jiang, J.; Biswas, P.; Schlager, J.J.; Hussain, S.M. Crystal structure mediates mode of cell death in $\mathrm{TiO}_{2}$ nanotoxicity. J. Nanopart. Res. 2009, 11, 1361-1374. [CrossRef]

69. Mercer, R.R.; Scabilloni, J.F.; Hubbs, A.F.; Battelli, L.A.; McKinney, W.; Friend, S.; Wolfarth, M.G.; Andrew, M.; Castranova, V.; Porter, D.W. Distribution and fibrotic response following inhalation exposure to multi-walled carbon nanotubes. Part Fibre Toxicol. 2013, 10, 33. [CrossRef]

70. Mohamed, H.R. Estimation of $\mathrm{TiO}_{2}$ nanoparticle-induced genotoxicity persistence and possible chronic gastritis-induction in mice. Food Chem. Toxicol. 2015, 83, 76-83. [CrossRef]

71. Geng, R.; Ren, Y.; Rao, R.; Tan, X.; Zhou, H.; Yang, X.; Liu, W.; Lu, Q. Titanium dioxide nanoparticles induced HeLa cell necrosis under UVA radiation through the ROS-mPTP pathway. Nanomaterials 2020, 10, 2029. [CrossRef]

72. Shi, H.; Magaya, R.; Castranova, V.; Zhao, J. Titanium dioxide nanoparticles: E review of current toxicological data. Part Fibre Toxicol. 2013, 10, 15. [CrossRef] [PubMed]

73. Häcker, G. The morphology of apoptosis. Cell Tissue Res. 2000, 301, 5-17. [CrossRef]

74. Li, J.; Yuan, J. Caspases in apoptosis and beyond. Oncogene 2008, 27, 6194-6206. [CrossRef] [PubMed]

75. Saraste, A.; Pulkki, K. Morphologic and biochemical hallmarks of apoptosis. Cardiovasc. Res. 2000, 45, 528-537. [CrossRef]

76. Tucci, P.; Porta, G.; Agostini, M.; Dinsdale, D.; Iavicoli, I.; Cain, K.; Finazzi-Agro, A.; Willis, A. Metabolic effects of TiO 2 nanoparticles, a common component of sunscreens and cosmetics, on human keratinocytes. Cell Death Dis. 2013, 4, e549. [CrossRef]

77. de Duve, C. Lysosomes revisited. Eur. J. Biochem. 1983, 137, 391-397. [CrossRef]

78. Iversen, T.G.; Skotland, T.; Sandvig, K. Endocytosis and intracellular transport of nanoparticles: Present knowledge and need for future studies. Nanotoday 2011, 6, 176-185. [CrossRef]

79. Kim, J.A.; Åberg, C.; Salvati, A.; Dawson, K.A. Role of cell cycle on the cellular uptake and dilution of nanoparticles in a cell population. Nat. Nanotechnol. 2011, 7, 62-68. [CrossRef] [PubMed]

80. Salvati, A.; Åberg, C.; dos Santos, T.; Varela, J.; Pinto, P.; Lynch, I.; Dawson, K.A. Experimental and theoretical comparison of intracellular import of polymeric nanoparticles and small molecules: Toward models of uptake kinetics. Nanomedicine 2011, 7, 818-826. [CrossRef] [PubMed]

81. Xu, Y.; Wang, J.; Song, X.; Wei, R.; He, F.; Peng, G.; Luo, B. Protective mechanisms of CA074-me (other than cathepsin-B inhibition) against programmed necrosis induced by global cerebral ischemia/reperfusion injury in rats. Brain Res. Bull. 2016, 120, 97-105. [CrossRef] [PubMed]

82. Terman, A.; Kurz, T.; Gustafsson, B.; Brunk, U.T. Lysosomal labilization. IUBMB Life 2006, 58, 531-539. [CrossRef]

83. Boya, P.; Kroemer, G. Lysosomal membrane permeabilization in cell death. Oncogene 2008, 27, 6434-6451. [CrossRef] [PubMed]

84. Kirkegaard, T.; Jäättelä, M. Lysosomal involvement in cell death and cancer. Biochim. Biophys. Acta 2009, 1793, 746-754. [CrossRef]

85. Stoka, V.; Turk, V.; Turk, B. Lysosomal cysteine cathepsins: Signaling pathways in apoptosis. Biol. Chem. 2007, 388, 555-560. [CrossRef] [PubMed]

86. Liu, L.; Zhang, X.; Yang, L.; Ren, L.; Wang, D.; Ye, J. Metal nanoparticles induced photocatalysis. Natl. Sci. Rev. 2017, 4, 761-780. [CrossRef]

87. Wang, C.; Wang, S.; Xia, Q.; He, W.; Yin, J.; Fu, P.P.; Li, J. Phototoxicity of zinc oxide nanoparticles in HaCaT keratinocytesgeneration of oxidative DNA damage during UVA and visible light irradiation. J. Nanosci. Nanotechnol. 2013, 13, 3880-3888. [CrossRef]

88. Lewicka, A.Z.; Yu, W.W.; Oliva, B.L.; Contreras, E.Q.; Colvin, V.L. Photochemical behavior of nanoscale $\mathrm{TiO}_{2}$ and $\mathrm{ZnO}_{\mathrm{n}}$ sunscreen ingredients. J. Photochem. Photobiol. A Chem. 2013, 263, 24-33. [CrossRef] 